\title{
Correction to: Reduced Serum Selenium Concentration in Miscarriage Incidence of Indonesian Subjects
}

\author{
Rizky Abdulah ${ }^{1,2} \cdot$ Herlambang herlambang $^{3} \cdot$ Leri Septiani $^{4} \cdot$ Mutakin $^{2,5} \cdot$ Irma R. Defi $^{2} \cdot$ Eka W. Suradji $^{2}$.

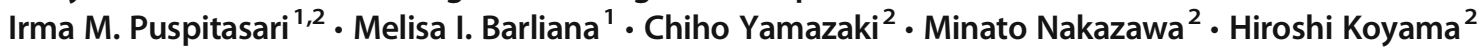

Published online: 26 September 2018

(C) Springer Science+Business Media, LLC, part of Springer Nature 2018

\section{Correction to: Biological Trace Element Research https://doi.org/10.1007/s12011-013-9701-0}

The original version of this article unfortunately contained a mistake. The name of "Herlambang herlambang" is now corrected in the author group of this article.

The online version of the original article can be found at https://oi.org/ 10.1007/s12011-013-9701-0

$\triangle$ Rizky Abdulah

abdulahrizky@gmail.com

1 Department of Pharmacology and Clinical Pharmacy, Faculty of Pharmacy, Universitas Padjadjaran, Jl. Raya Bandung Sumedang Km. 21, Jatinangor 45363, Indonesia

2 Department of Public Health, Gunma University Graduate School of Medicine, Maebashi, Japan

3 Department of Obstetrics and Gynecology, Faculty of Medicine and Health Sciences, Universitas Jambi, Jambi, Indonesia

4 Department of Obstetrics and Gynecology, Faculty of Medicine, Universitas Padjadjaran - Hasan Sadikin Hospital,

Bandung, Indonesia

5 Department of Pharmaceutical Analysis and Medicinal Chemistry, Faculty of Pharmacy, Universitas Padjadjaran, Bandung, Indonesia 